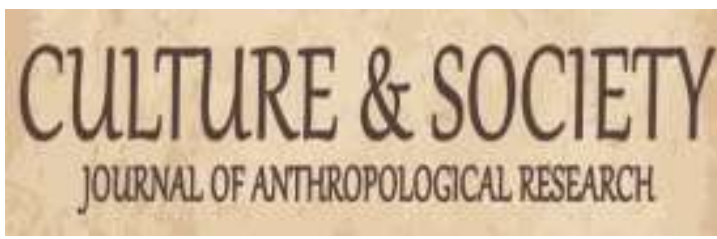

Culture \& Society: Journal of Anthropological Research

VOL. 3 NO. 2 DESEMBER 2021

http://culture.ppj.unp.ac.id

Email: culture@ppj.unp.ac.id

ISSN: 2686-343X (E-ISSN) 2686-3421 (P-ISSN)

DOI: https://doi.org/10.24036/csjar.v3i2.84

\title{
Partisipasi Masyarakat dalam Pengembangan Wisata Bahari Pulau Kapoposang Kabupaten Pangkep Sulawesi Selatan
}

\author{
Andi Oktami Dewi Artha Ayu Purnama ${ }^{1}$ \\ ${ }^{1}$ IAIN Sultan Amai Gorontalo
}

\author{
Email: oktamidewi@iaingorontalo.ac.id
}

\begin{abstract}
Abstrak
Partisipasi masyarakat dalam pengembangan wisata bahari merupakan suatu kewajiban dengan mengingat bahwa potensi bahari adalah milik bersama dan yang terpenting dengan adanya partisipasi, masyarakat akan lebih memiliki kesadaran mengenai potensi bahari yang dimilikinya dan harus terus menerus dilindungi agar dapat memberikan kehidupan bagi masyarakat. Penelitian ini bertujuan untuk menggambarkan serta menganalisis keterlibatan multi pihak dan bentuk partisipasi masyarakat dalam pengembangan wisata bahari, menggunakan deskriptif kualitatif dengan sumber data diperoleh dari katakata dan tindakan informan yang selebihnya adalah data tambahan seperti dokumen dengan teknik purposive. Data yang diperoleh dikumpulkan melalui observasi (observation), wawancara mendalam (in depth interview) dan dokumentasi. Analisis data dilakukan dengan metode kualitatif melalui tiga tahap yaitu tahap reduksi data, penyajian data dan penarikan kesimpulan. Hasil penelitian menunjukkan, keterlibatan masyarakat masih berkisar pada kelompok-kelompok masyarakat dan penyediaan sarana prasarana oleh pihak swasta sementara masyarakat hanya dilibatkan sebatas perencanaan sedangkan pada proses pelaksanaan dan pemanfaatannya masyarakat sudah tidak dilibatkan. Dalam partisipasi masyarakat inilah disebut "partisipasi pasif" karena berdasarkan hasil analisis dan beberapa poin yang belum terpenuhi oleh masyarakat seperti pengelolaan wisata kolaborasi yang melibatkan seluruh stakeholder dan pemberdayaan masyarakat yang pada akhirnya menimbulkan partisipasi interaktif yang di mana masyarakat Kapoposang ikut serta dalam pengelolaan pulaunya sendiri dengan pengambilan keputusan bersifat lokal dan menentukan bagaimana ketersediaan sumber daya yang digunakan, sehingga memiliki kekuasaan untuk menjaga potensi yang ada di lingkungannya.
\end{abstract}

Kata kunci: Partisipasi Masyarakat, Pengembangan Wisata, Wisata Bahari

\section{Abstract}

Community participation in marine tourism is an obligation by remembering that the marine potential is shared and most importantly with participation, the community will have more awareness of the marine potential that must be maintained to provide life for the community. This study aims to describe and analyze multi-stakeholder involvement and forms of community participation in the development of marine tourism, using qualitative descriptive with data sources obtained from words and action information, the rest is additional data such as documents with purposive techniques. The data obtained were collected through observation, in-depth interviews, and documentation. Data analysis was carried out using qualitative methods through three stages, namely the data reduction stage, data presentation, and conclusion drawing. The results of the study show that community involvement still revolves around community groups and the provision of infrastructure by the private sector while the community is only involved in planning while in the implementation and utilization process the community is not involved. This community participation is called "passive participation" because it is based on the results of the analysis and several points that have not been met by the community, such as collaborative tourism management that involves all stakeholders and community empowerment which ultimately leads to interactive participation in which the Kapoposang community participates in managing their island by Decision making is local and determines the availability of the resources so that it has the power to maintain the potential that exists in its environment.

Keywords: Community Participation, Marine Tourism, Tourism Development

\begin{tabular}{|c|c|c|}
\hline Received: October 21, 2021 & Revised: December 16, 2021 & Published: December 20, 2021 \\
\hline
\end{tabular}

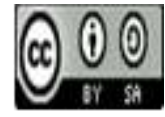

Culture \& Society: Journal of Anthropological Research Vol. 3, No. 2, Th. 2021

2686-343X (E-ISSN) 2686-3421 (P-ISSN)

Copyright () 2021, by Author. 


\section{Pendahuluan}

Indonesia adalah negara kepulauan yang kaya akan objek pariwisata yang tersebar dari Sabang sampai Merauke. Perkembangan pariwisata di Indonesia mengalami kemajuan yang sangat pesat ketika pemerintah memutuskan untuk mengandalkan sektor pariwisata sebagai penghasil devisa terbesar bagi negara. Kemajuan yang sangat pesat ini terjadi di pulau Bali, karena Bali sangat terkenal di dunia internasional. Padahal kalau kita lihat masih banyak daerah di Indonesia bahkan pulau-pulau yang mempunyai potensi yang sama untuk dijadikan sebagai daerah tujuan wisata, hanya saja masih banyak daerah yang kurang mendapat perhatian dari pemerintah.

Pemerintah mengambil langkah strategis dalam pengembangan pariwisata nasional, dengan menyerahkan pembinaanya kepada Pemerintah Daerah Kabupaten/Kota dengan tujuan dapat memudahkan pengembangan dan koordinasi pembangunan daerah. Pemerintah Daerah maupun lembaga-lembaga swasta telah berusaha membangun area rekreasi semampu mungkin dengan memanfaatkan lahan, didukung oleh daya dan dana yang ada untuk penyaluran kebutuhan akan rekreasi tersebut (Binarwan, 2008).

Pengembangan merupakan strategi yang dipergunakan untuk memajukan, memperbaiki dan meningkatkan kondisi kepariwisataan suatu objek dan daya tarik wisata sehingga dapat dikunjungi wisatawan serta mampu memberikan manfaat bagi masyarakat disekitar objek dan daya tarik wisata maupun bagi pemerintah (Paturusi, 2001). Pengembangan di daerah pariwisata memiliki pengaruh sangat positif bagi pertumbuhan ekonomi daerah dan masyarakat setempat. Selain itu, sektor pariwisata juga dapat membantu pelestarian nilai dan budaya lokal, serta berpotensi menjadi jembatan dalam perbedaan sosial budaya dan kesenjangan ekonomi masyarakat. Namun, jika tidak dikembangkan secara terencana maka pariwisata juga akan memberikan peluang bagi munculnya berbagai dampak negatif yang merugikan kehidupan ekonomi, sosial dan budaya di daerah yang bersangkutan. Oleh sebab itu, kebijakan pengembangan sektor pariwisata didaerah haruslah memperhitungkan secara cermat baik dampak positif maupun negatifnya. Peran pemerintah daerah sebagai inisiator, motivator dan fasilitator sangat menentukan keberhasilan pengembangan pariwisata.

Partisipasi masyarakat diperlukan dalam setiap kegiatan yang akan dilaksanakan. Keterlibatan masyarakat mulai dari perencanaan sampai pelaksanaan merupakan unsur utama dalam sistem pengembangan wisata. Partisipasi menurut Isbandi (2007) adalah keikutsertaan masyarakat dalam proses mengidentifikasian masalah dan potensi yang ada di masyarakat, pemilihan dan pengambilan keputusan tentang alternatif solusi untuk menangani masalah, pelaksanaan upaya mengatasi masalah, dan keterlibatan masyarakat dalam proses mengevaluasi perubahan yang terjadi. Masyarakat ikut serta atau berperan aktif dengan pemerintah untuk menjamin keberhasilan pembangunan. Partisipasi di sini bisa berupa partisipasi buah pikiran atau ide, partisipasi ketrampilan atau tenaga, partisipasi sosial dan partisipasi dalam pelaksanaan program.

Sulawesi Selatan merupakan salah satu daerah tujuan wisata di Indonesia, ini dilihat dengan meningkatnya kunjungan wisatawan mancanegara dan wisatawan nusantara ke Sulawesi Selatan, maka perkembangan di bidang pariwisata pun mengalami kemajuan yang sangat pesat. Hal ini dapat dilihat dari pesatnya pembangunan prasarana dan sarana wisata seperti pembangunan hotel, bertambahnya travel agen, dijadikannya Bandar Udara Sultan Hasanuddin sebagai bandar udara internasional dan makin dikembangkannya tempat-tempat wisata lainnya.

Salah satu Daerah Tujuan Wisata (DTW) Sulawesi Selatan adalah Kabupaten Pangkajene dan Kepulauan (Pangkep) yang banyak memiliki potensi alam objek wisata bahari yang menarik dan salah satunya ialah Pulau Kapoposang. Pulau Kapoposang sebagai bagian dari Kabupaten Pangkep yang memiliki daya tarik untuk dikembangkan sebagai daerah tujuan wisata, baik utuk

Culture \& Society: Journal of Anthropological Research Vol. 3, No. 2, Th. 2021 
pasar wisata nusantara maupun mancanegara. Pulau Kapoposang yang mempunyai potensi sebagai objek wisata yang didukung oleh keberadaannya sebagai suatu kawasan yang memiliki potensi sangat besar. Beberapa potensi yang ada di Pulau Kapoposang adalah keanekaragaman hayatinya yang tinggi, terutama di lingkungan terumbu karang. Pulau Kapoposang juga merupakan kawasan yang memiliki keindahan alam dengan hutan yang masih asli, pantai berpasir putih dengan terumbu karang yang mengelilingi pulau-pulau, adanya burung maleo dan penyu sisik. Selain itu, potensi sumber daya Kapoposang terbilang tinggi, baik wisata bahari maupu wisata lingkungan dan rekreasi yang ditunjukkan oleh skala nasional maupun Internasional.

Ditetapkannya Kawawasan Kapoposang sebagai Taman Wisata Perairan Kepulauan Kapoposang (TWP Kepulauan Kapoposang) oleh Menteri Kelautan dan Perikanan melalui Kep.66/Men/2009 pada 3 September 2009. Dengan berbagai potensi yang dimilikinya maka pulau ini banyak dilakukan pengembangan wisata bahari dan banyak dikunjungi oleh wisatawan mancanegara maupun wisatawan lokal.

Masyarakat merupakan salah satu unsur utama dalam pengembangan objek wisata yang saat ini semakin dituntut peran sertanya. Sebetulnya sudah sejak lama model pengembangan partisipatif dikembangkan yang melibatkan masyarakat bahkan menempatkan masyarakat sebagai pelaku utama dari pengembangan yang sedang dan akan berlangsung, namun dalam penerapannya masih banyak terdapat kelemahan terutama dalam bentuk koordinasi antara pemerintah, swasta dan masyarakat.

Penelitian mengenai partisipasi masyarakat dalam pengembangan wisata bahari sudah dilakukan oleh Ghofar, dkk (2017) namun pada penelitian ini memiliki lokus yag berbeda dan penggambaran yang berbeda. Riset ini dianalisa dengan konsep pengembangan objek wisata, keterlibatan multi-pihak dan keterlibatan masyarakat. Karena dengan berbagai program akan berjalan baik apabila masyarakat memiliki keterlibatan secara langsung baik dalam peningkatan serta pemeliharaan prasarana pariwisata dan dalam pengembangan pariwisata akan kurang berarti apabila masyarakat lokal itu sendiri tidak ikut berpartisipasi dalam sektor pariwisata terutama di Pulau Kapoposang. Dalam hal ini akan dilihat bentuk partisipasi dari masyarakat yang merupakan langkah awal untuk membangun kerjasama antara pembuat kebijakan dengan masyarakat sebagai upaya pendorong suksesnya kebijakan dalam rangka pengembangan objek wisata.

\section{Metode Penelitian}

Penelitian ini dilakukan di Pulau Kapoposang, Desa Mattiro Ujung, Kecamatan Liukang Tupabiring Kabupaten Pangkajene dan Kepulauan Sulawesi Selatan. Penentuan lokasi dilakukan secara sengaja (purposive). Pemilihan lokasi yang didasarkan atas pertimbangan bahwa lokasi ini terletak pada daerah yang dijadikan sebagai Taman Wisata Perairan Kepulauan Kapoposang oleh Kementerian Kelautan dan Perikanan dan merupakan tempat wisata bahari yang dikelilingi oleh masyarakat di mana mata pencaharian pokok mereka adalah menangkap ikan/ nelayan, di mana masyarakat akan ikut terlibat dalam pengembangan objek wisata bahari tersebut. Penelitian ini menggunakan pendekatan kualitatif di mana data yang diperoleh berasal dari lapangan dengan melakukan pengamatan dan wawancara mendalam dengan informan yang mengerti tentang pengembangan objek wisata bahari di Pulau Kapoposang, mengetahui potensi sosial budaya yang dimiliki Pulau Kapoposang dan bentuk partisipasi masyarakat dalam pengembangan wisata bahari. Tipe penelitian yang digunakan ialah penelitian deksriptif (Descriptive Research) yaitu penelitian yang menggambarkan atau melukiskan situasi tertentu berdasarkan data yang diperoleh secara rinci sesuai dengan permasalahan yang ditetapkan dalam penelitian ini. Pengumpulan data menggunakan observasi (observation), wawancara mendalam (in depth interview) dan dokumentasi. Analisis data dilakukan melalui tiga tahap yaitu tahap

Culture \& Society: Journal of Anthropological Research Vol. 3, No. 2, Th. 2021 
reduksi data, penyajian data dan penarikan kesimpulan. Melalui pengumpulan data tersebut dapat diketahui bentuk partisipasi masyarakat dalam pengembangan objek wisata bahari di Pulau Kapoposang, Kabupaten Pangkajene dan Kepulauan, Sulawesi Selatan.

\section{Hasil dan Pembahasan}

\section{Keterlibatan Multi Pihak}

Partipasi berkaitan dengan keterlibatan mental dan emosional orang-orang dalam situasi kelompok yang mendorong mereka untuk memberikan kontribusi kepada tujuan kelompok dan berbagai tanggung jawab pencapaian tujuan itu (Davis dan Newstrom dalam Sallatu, 2007). Ada tiga gagasan penting dari definisi Davis dan Newstrom tersebut, yaitu: pertama, keterlibatan, partisipasi berarti adanya keterlibatan mental dan emosional daripada hanya berupa aktivitas fisik. Keterlibatan ini bersifat psikologis sehingga seseorang yang berpartisipasi terlibat emosinya dan bukan hanya terlibat karena tugasnya. Kedua, kontribusi dalam partisipasi yang sangat penting adalah motivasi orang-orang untuk memberikan kontribusi mereka diberi kesempatan untuk menyalurkan inisiatif dan kreatifitasnya guna mencapai tujuan bersama organisasi. Ketiga, tanggung jawab, bahwa partisipasi mendorong orang-orang untuk menerima tanggung jawab dalam aktivitas kelompok. Disini terjadi proses sosial orang-orang menjadi terlibat sendiri dalam organisasi dan pada akhirnya mereka bertanggungjawab menyelesaikan pekerjaannya.

Dengan keterlibatan stakeholder akan melahirkan rasa mampu mendorong untuk memberikan kontribusi dan berbagai tanggung jawab guna mencapai tujuan. Pengguna atau yang sering disebut stakeholder yang terlibat di Pulau Kapoposang terdiri dari unsur Pemerintah Daerah Kabupaten Pangkep, perusahaan swasta PT. Makassar Tirta Wisata, Balai Kawasan Konservasi Perairan Nasional (BKKPN) Kupang, Lantamal VI Makassar dan masyarakat Pulau Kapoposang yang memiliki kepentingan langsung maupun tidak langsung terhadap sumber daya Pulau Kapoposang. Saat ini yang berperan dalam pengelolaan sumber daya Pulau Kapoposang adalah pihak swasta.

Secara keseluruhan pihak swasta PT. Makassar Tirta Wisata memegang peranan yang sangat besar dalam pengembangan wisata bahari di Pulau Kapoposang. Namun ada Permasalahan internal kelembagaan Pulau Kapoposang disebabkan oleh masih rendahnya sumber daya manusia pelaku wisata dalam memahami konsep wisata bahari, belum adanya tokoh masyarakat yang dijadikan panutan dalam menggerakkan masyarakat, dan keperccayaan dari masyarakat belum terbangun secara utuh dan permasalahan eksternal lebih disebabkan oleh kurangnya jalinan kerjasama dengan pihak-pihak terkait, baik pemerintah, forum komunikasi masyarakat dan dunia usaha/swasta.

Dari permasalaha tersebut, pengembangan kelembagaan ini memerlukan perencanaan partisipatif (participatory planning) di mana masyarakat dianggap sebagai mitra dalam perencanaan yang turut berperanserta secara aktif baik dalam hal penyusunan maupun implementasi rencana, karena walau bagaimana pun masyarakat merupakan stakeholder terbesar dalam penyusunan sebuah produk rencana (Ndraha dalam Saktiawan, 2008).

\section{Pemerintah Daerah}

Pemerintah Daerah Kabupaten Pangkep sudah melakukan berbagai upaya dalam pengembangan program sesuai kebijakan kepariwisataan pada tingkat daerah, provinsi, nasional dan internasional. Pemerintah Kabupaten Pangkep sejak lama telah melakukan berbagai kebijakan, program dan kegiatan, seperti mengembangkan kebijakan pembangunan kepariwisataan daerah, mengembangkan sosialisasi dan komunikasi pada tingkat desa, kecamatan, kabupaten dan nasional, mengupayakan program peningkatan partisipasi masyarakat setempat dalam kegiatan bahari, pemberian ijin pengembangan wisata bahari kepada semua pihak, melakukan kerjasama dengan berbagai pihak dalam pengembangan wisata bahari,

Culture \& Society: Journal of Anthropological Research Vol. 3, No. 2, Th. 2021 
pembangunan sarana dan prasarana, membuat peraturan daerah mendukung pengembangan wisata bahari.

Berbagai kebijakan pembangunan kepariwisataan ini salah satunya ditujukan untuk meningkatkan dan membantu masyarakat dalam meningkatkan partisipasi masyarakat setempat pada kawasan terumbu karang dalam kegiatan wisata bahari. Pada taraf tertentu memang telah terjadi proses perbaikan pandangan, wawasan, pengetahuan, kesadaran, dan perilaku masyarakat terhadap program pembangunan wisata bahari. Dalam proses perbaikan itu belum disertai dengan perbaikan ekonomi masyarakat dan berfikir dampak dari program wisata bahari. Berbagai kendala masih cukup banyak dihadapi masyarakat setempat pada aspek internal maupun eksternal sebagaimana yang diungkapkan Kepala Dusun Kapoposang.

"Pemerintah Daerah Kabupaten Pangkep pernah memerintahkan masyarakat membuat homestay tapi karena kendala modal jadi sampai sekarang saya hanya menyiapkan rumah saya setiap ada yang datang berkunjung ketempat ini dan sudah banyak juga yang datang berkunjung kesini mulai dari pejabat, angkatan laut sampai puluhan mahasiswa"

"Tahun lalu ada pembangunan resort pengusaha dari Bali namanya pak Rudy. Dia sudah membangun 1 resort tapi karena belum mendapat ijin dari pemerintah Kabupaten dan saya sebagai Dusun Kapoposang pembangunannya dihentikan"

Pemerintah Kabupaten Pangkep masih perlu melakukan berbagai program untuk terus berusaha meningkatkan partisipasi, keterlibatan dan penguatan masyarakat dalam upaya meningkatkan peran dan fungsi masyarakat dalam program wisata bahari di pulaunya.

\section{Balai Kawasan Konservasi Perairan Nasional (BKKPN) Kupang}

Balai Kawasan Konservasi Perairan Nasional (BKKPN) di pulau ini cukup banyak melakukan berbagai upaya di Kabupaten Pangkep. Sebelum diserahterimakan pengelolaannya kepada BKKPN yang dinaungi oleh Departemen Kelautan dan Perikanan, Pulau Kapoposang ini dikelola oleh Balai Konservasi Sumber Daya Alam (BKSDA) dibawah naungan Kehutanan berdasarkan pada berita acara tanggal 4 Maret 2009 dengan nomor BA 01/Menhut-IV/2009 dan BA 108/Men.KP/III/2009.

Pemetaan zonasi Pulau Kapoposang yang melibatkan BKKPN dalam proses perencanaan melibatkan masyarakat selanjutnya pada proses penanda pada zona inti masyarakat tidak dilibatkan. Masyarakat mengemukakan tentang zona inti di Pulau Kapoposang.

"Kalau zona inti masyarakat tau ada zona inti tapi kita tidak pernah diberi tahukan di mana tempatnya itu zona inti. Tidak pernah ada sosialisasi kepada masyarakat tentang itu zona inti. Dulu pernah ada tanda tapi sekarang sudah tidak ada bagaimana bahannya terbuat dari bahan yang mudah dibawa arus"

Berbeda dengan pendapat Kepala Dusun Kapoposang mengenai peta zonasi Taman Wisata Perairan Pulau Kapoposang

"Ada sosialisasi perencanaan zonasi tapi hanya beberapa orang yang datang jadi banyak juga masyarakat tidak tau tentang zona inti"

Pada saat pemetaan zonasi hanya kelompok masyarakat yang ikut dalam sosialisasi tetapi pada saat penandaan zonasi mayarakat tidak pernah mendapat pemberitahuan tentang keberadaan zona inti yang akhirnya pengetahuan masyarakat tetang zona inti tidak ada.

Culture \& Society: Journal of Anthropological Research Vol. 3, No. 2, Th. 2021 
Walaupun di pulau tersebut sudah diadakan papan tampilan peta zonasi Taman Wisata Perairan Kepulauan Kapoposang tetapi masyarakat tidak paham karena faktor pendidikan mereka walaupun mereka mengerti apa kegunaan zonasi tetapi masyarakat tidak mengerti dalam pembacaan peta letak zonasi.

BKKPN telah melakukan berbagai upaya berarti tetapi upaya itu masih perlu terus dilakukan dari sisi lainnya, seperti bagaimana masyarakat tidak hanya menjadi penyedia kelapa muda dan ikan bagi kepentingan wisatawan, bagaimana pula membuat sosialisasi agar penduduk tidak melakukan kegiatan yang kurang menunjang pengembangan wisata bahari seperti wisatawan (mancanegara dan nusantara) hanya dijadikan tontonan bagi masyarakat yang membuat rasa tidak atau kurang aman, nyaman, senang dan bebas menikmati aktivitas wisata baharinya. Pengetahuan dan pemahaman tentang aspek ini perlu diberitahukan pada masyarakat sehingga tercipta suatu nilai dan sistem sosial yang lebih mampu mendukung pengembangan wisata bahari di kawasannya. Bagaimana pula agar kebutuhan turis itu terpenuhi. Upaya-upaya ini akan membuat dampak wisata bahari terhadap perbaikan sosial ekonomi masyarakat semakin membaik.

\section{Usaha Perjalanan Wisata/Travel}

Pihak Travel PT. Makassar Tirta Wisata (Makassar Diving Center) selama ini memang yang lebih diuntungkan dalam wisata bahari adalah pihak swasta yang mampu menyediakan sarana dan prasarana wisata bahari yang dibutuhkan wisatawan mancanegara dan domestik. PT. Makassar Tirta Wisata (Makassar Diving Center) adalah milik Julia Pupella dan Andi Ilhamsyah Mattalatta. Julia Pupella mengemukakan tentang pengelolaan Pulau Kapoposang.

"Kami punya izin tunggal mengelola Pulau Kapoposang dari Pemkab Pangkep.

Sebagai pengelola, kami tidak hanya mencari profit, tetapi juga komitmen menjaga

kelestarian pantai dan biota laut di kawasan pulau ini".

Pulau Kapoposang cukup digemari penghobi diving, mancing dan snorkling khususnya turis asing. Untuk masuk ke Pulau Kapoposang, pengelola menjual wisata secara paket yang minimal perpaket empat orang. Semakin banyak rombongan maka biaya yang dikeluarkan setiap orang akan semakin kecil. Keberangkatan menuju Pulau Kapoposang dari pelabuhan POPSA Kota Makassar dengan menggunakan speed boat hanya memakan waktu 1 jam 15 menit.

Pola penjualan paket wisata ini pengujung tidak perlu lagi membawa uang tunai karena paket yang ditawarkan cukup sesuai dengan fasilitas yang akan dinikmati pelancong. Setiap paket sudah termasuk penginapan dan makan empat kali sehari. Selain itu, sudah tersedia speed boat dan guide bagi wisatawan. Setiap kamar diengkapi dengan AC dan kamar mandi dalam yang bersih.

Hampir semua stakeholder yang berhasil diwawancarai mengungkapkan bahwa tingkat partisipasi dan keterlibatan masyarakat dalam pengelolaan bahari di Pulau Kapoposang masih sangat rendah karena masyarakat hanya dilibatkan sebatas sosialisasi selanjutnya dalam pelaksanaan masyarakat tidak dilibatkan.

Model penyelenggaraan wisata bahari yang dilakukan pihak PT. Makassar Tirta wisata (Makassar Diving Center) memang menunjukkan hampir seluruh kegiatan didominasi oleh mereka sebagai penyelenggara. Pendapatan yang diterima pihak pengusaha ini jauh lebih banyak dibandingkan dengan masyarakat setempat di mana areanya digunakan untuk kepentingan penyelaman. Kondisi seperti ini sangat wajar apabila masyarakat setempat "melarang", "menghalangi", atau "membatasi" pihak swasta melakukan atau mengembangkan kegiatan usahanya. Apabila masyarakat merasa mendapatkann aspek positif dari kegiatan wisata bahari di Kapoposang maka sangat memungkinkan sekali untuk menunjang setiap kegiatan wisata bahari di pulaunya. Semakin tinggi partisipasi suatu masyarakat maka semakin tinggi pula dampak positif wisata bahari terhadap masyarakat tersebut. Ini menjadi prospek yang sangat

Culture \& Society: Journal of Anthropological Research Vol. 3, No. 2, Th. 2021 
menjanjikan untuk meningkatkan kesejahteraan masyarakat di pulau. Salah satu karyawan PT. Makassar Tirta Wisata mengemukakan tentang pengelolaan swasta pada wisata bahari di Pulau Kapoposang.

"Yang bekerja dalam pariwisata Pak Andi ada 8 Karyawan tidak ada orang lain didalam, 2 anak kandung dari pak Jabar, 1 cucu, 2 menantu, 2 sepupu 1x dan 1 pak Jabar sendiri. Mereka merupakan keluarga inti dari pak Jabar. Pak Jabar ini pemilik lokasi tempat Pak Andi membangun villanya, pak Andi kontrak sekitar 40 tahun dan sekarang sudah ada 20 tahun. Yang jadi instruktur juga buat wisatawan dibawa langsung dari Makassar, semua bahan makanan juga dibawa langsung dari Makassar"

Pernyataan dari pihak PT. Makassar Tirta Wisata ini menunjukkan bahwa masyarakat tidak ada yang terlibat dalam kegiatan wisata bahari di pulau ini. Hanya orang yang berkepentingan yang bisa menjadi bagian dari wisata bahari maka ini merupakan indikator bahwa dampak pembangunan wisata bahari terhadap kehidupan sosial ekonomi masyarakat sampai saat ini belum terjadi.

Apabila masyarakat terus tidak diuntungkan dalam program pengembangan dan pengelolaan wisata bahari, maka bisa saja akan terjadi di mana masyarakat sebagai "pemilik" atau "penguasa" adat kawasan wisata bahari melakukan upaya-upaya sistematis dan berencana untuk membatasi program pengembangan wisata bahari di daerahnya. Masyarakat memang tidak harus menjadi kelompok yang terus dikorbankan, kurang diperhatikan dan kurang diuntungkan dalam kebijakan pembangunan wisata bahari. Pendekatan baru yang lebih bisa memberikan peluang atau kesempatan kepada masyarakat untuk mengembangkan dirinya perlu dikembangkan. Kurangnya keterlibatan masyarakat dalam proses pembangunan akan semakin menimbulkan gap yang semakin besar antara "pemiliki" sumber daya alam dengan para pengusaha wisata bahari di wilayahnya. Pengembangan kebijakan dan tindakan yang lebih berpihak pada masyarakat asli memang perlu dikembangkan untuk semakin memberdayakan dan menguatkan masyarakat dalam proses menunjang pembangunan wisata bahari didaerahnya.

\section{Lantamal VI Makassar}

Program kemitraan dalam pelatihan selam bagi masyarakat Kapoposang yang bersinergi antara BP PAUDNI Regional III dengan LANTAMAL VI Makassar ini guna untuk pemberdayaan masyarakat pesisir yang bertujuan agar masyarakat Pulau Kapoposang tak hanya menggantungkan hidupnya sebagai nelayan semata. Khususnya untuk Pulau Kapoposang sebagai sarana untuk penyadaran diri bahwa laut harus dijaga untuk keberlangsungan ekosistem laut seperti terumbu karang dan lain-lain. Setelah pelatihan ini juga diharapkan bahwa nantinya kesepuluh pemuda penyelam ini bisa berperan aktif dalam menggiatkan wisata bahari dalam Pulau Kapoposang.

Pada kesempatan ini pula Lantamal VI Makassar melaksanakan pendidikan keaksaraan kepada masyarakat Pulau Kapoposang yang belum bisa membaca dan menulis yang berjumlah 15 orang. Metode yang diterapkan adalah Keaksaraan Fungsional yaitu belajar membaca yang dirangkaikan dengan suatu kegiatan seperti pembuatan kue wingko, jus kelapa muda, pembuatan sayur dari batang pisang yang di mana semua bahan bakunya tersedia di Pulau tesebut.

\section{Bentuk Partisipasi Masyarakat}

Partisipasi masyarakat dalam kegiatan wisata bahari ini merupakan bagian yang sangat penting dalam pengembangan kepariwisataan di pulau ini. Indikator pengembangan wisata bahari dapat diperhatikan dari sejauhmana keterlibatan pemerintah, swasta dan masyarakat

Culture \& Society: Journal of Anthropological Research Vol. 3, No. 2, Th. 2021 
saling bersinergi dalam berbagai kegiatan pengembangan pariwisata ini. Partisipasi berarti "mengambil bagian", atau menurut Hoofsteede "The Taking Part in one or more phase of the process" (partisipasi) berarti ambil bagian dalam suatu tahap atau lebih dari suatu proses (Khairuddin, 1992). Mubyarto dalam Ndraha (1987) mendefinisikan partisipasi sebagai kesediaan untuk membantu berhasilnya setiap program sesuai kemampuan setiap orang tanpa berarti mengorbankan diri sendiri.

Cohen dan Uphoff (1979) membagi partisipasi ke beberapa tahapan, sebagai berikut.

1) Tahap pengambilan keputusan, yang diwujudkan dengan keikutsertaan masyarakat dalam rapat-rapat. Tahap pengambilan keputusan yang dimaksud disini yaitu perencanaan dan pelaksanaan suatu program.

2) Tahap pelaksanaan yang merupakan tahap terpenting dalam pembangunan, sebab inti dari pembangunan adalah pelaksanaannya. Wujud nyata partipasi pada tahap ini digolongkan menjadi tiga, yaitu partisipasi dalam bentuk sumbangan pemikiran, bentuk sumbangan materi, dan bentuk Tindakan sebagai anggota proyek.

3) Tahap evaluasi, dianggap penting sebab partisipasi masyarakat pada tahap ini merupakan umpan balik yang dapat memberi masukan demi perbaikan pelaksanaan proyek selanjutnya.

4) Tahap menikmati hasil, yang dapat dijadikan indikator keberhasilan partisipasi masyarakat pada tahap perencanaan dan pelaksanaan proyek. Selain itu, dengan melihat posisi masyarakat sebagai subjek pembangunan, maka semakin besar manfaat proyek dirasakan, berarti proyek tersebut berhasil mengenai sasaran.

Dari keseluruhan ringkat partisipasi diatas merupakan kesatuan integratif dari kegiatan pengembangan dan pengelolaan wisata bahari, meskipun sebuah siklus konsisten dari kegiatan partisipasi mungkin dinilai belum biasa. Dalam hal ini, masyarakat merupakan pihak yang paling yang berhak menentukan, merencanakan dan terlibat langsung dalam pengembangan dan pengelolaan wisata karena masyarakat yang paling terkena dampak maupun perubahan yang terjadi dari suatu kegiatan wisata. Berkaitan dalam hal tersebut partisipasi masyarakat dalam penelitian ini adalah keterlibatan masyarakat memiliki 3 tahapan dimulai dari tahap sosialisasi, tahap persiapan dan tahap pelaksanaan.

\section{Partisipasi pada tahap sosialisasi}

Keterlibatan masyarakat pada tahap sosialisasi program diukur dari seberapa sering mereka mendengar dan mengikuti kegiatan sosialisasi yang dilakukan oleh pemerintah daerah, swasta maupun pihak lain. Semakin sering mengikuti program sosialisasi maka semakin tinggi partisipasinya pada kegiatan pengembangan wisata bahari.

Masyarakat menyatakan pernah mengikuti kegiatan sosialisasi tentang rencana pembangunan dan pengembangan Pulau Kapoposang yang dilakukan oleh pihak pemerintah daerah dan pihak swasta. Masyarakat juga menyatakan pernah mengikuti sosialisasi pada penetapan zonasi Pulau Kapoposang sesuai yang diungkapkan sebagai berikut:

"Sudah 2 kalimi diadakan pertemuan antara masyarakat, pemerintah dan pengusaha untuk ini wisata tapi tetapji masyarakat tidak didengar. Pemerintah pernah bilang kalau mau didatangkan wisatawan masyarakat harus punya homestay, setelah ada masyarakat yang buat homestay sampai sekarang itu homestay tidak pernah didatangi wisatawan sampai sekarang juga tidak ada tindak lanjut dari pemerintah".

Ini menunjukkan bahwa tingkat keterlibatan masyarakat dalam mengikuti sosialisasi program pengembangan wisata ini cukup tinggi, yang berarti mengindikasi bahwa partisipasi masyarakat dalam pengembangan wisata dapat dikatakan tinggi walaupun masih dalam tahap

Culture \& Society: Journal of Anthropological Research Vol. 3, No. 2, Th. 2021 
sosialisasi. Kehadiran pejabat-pejabat baik pada kunjungan kedinasan maupun pada hari libur memberi kesan positif terhadap pengembangan pulau.

\section{Tahap Persiapan}

Pada tahap persiapan adalah tahap di mana pengelola program melakukan kegiatan pertemuan kepada masyarakat, rapat teknis kegiatan dan identifikasi masalah yang berhubungan dengan rencana promosi kepada para investor. Kegiatan ini dihadiri oleh jajaran aparat kecamatan dan desa serta tokoh-tokoh masyarakat serta masyarakat umum. Kepala Dusun Kapoposang mengemukakan pendapatnya tentang persiapan yang dilakukan sebelum terlaksananya kegiatan pengembangan di Pulau Kapoposang.

"Ada pertemuan sebelum melakukan kegiatan di Kapoposang dan semua masyarakat di panggil tapi banyak juga masyarakat yang tidak datang pada saat pertemuan, hanya kelompok masyarakat yang datang ke pertemuan".

Hanya sebagian masyarakat yang aktif mengikuti kegiatan persiapan pelaksanaan pengembangan wisata bahari. Pada kegiatan pertemuan ini diikuti secara seksama. Hal ini juga terlihat dari masyarakat yang menyatakan aktif mengikuti kegiatan rapat teknis dan kegiatan identifikasi masalah.

\section{Tahap pelaksanaan kegiatan}

Pada tahap ini pengelola proyek dalam hal ini pihak Pemerintah Daerah Kabupaten Pangkep, pihak swasta, pihak pemerintah desa serta tokoh-tokoh masyarakat setempat seharusnya secara bersama-sama memberi pemahaman kepada masyarakat tentang manfaat yang diterima oleh masyarakat sehubungan dengan wisata bahari di Pulau Kapoposangn dan memberikan ruang kepada masyarakat agar bisa menghasilkan dari potensi Pulau Kapoposang. Manfaat yang dirasakan masyarakat dalam wisata bahari antara lain.

- Terbukanya kesempatan kerja bagi penduduk setempat.

- Pengembangan berbagai kegiatan usaha produktif.

- Adanya perbaikan infrastruktur pulau ini misalnya transportasi yang semakin baik, listrik, serta sarana dan prasarana lainnya yang dapat dinikmati oleh masyarakat.

- Meningkatnya kesejahteraan masyarakat secara umum.

Tetapi kenyataannya pada tahap pelaksanaan partisipasi masyarakat di Pulau Kapoposang tidak dilibatkan apalagi untuk membukakan ruang bagi masyarakat untuk ikut bergabung dalam wisata bahari di Pulau Kapoposang. Pada umumnya masyarakat memberi respon positif terhadap kegiatan wisata bahari. Hal ini terlihat dari kesediaan mereka untuk tidak mempermasalahkan rumah mereka dijadikan tempat penginapan bagi wisatawan, mereka juga mau mempersiapan untuk kebutuhan wisatawan selama di Kapoposang.

Berdasarkan penjelasan dari informan dapat disimpulkan bahwa masyarakat aktif secara optimal hanya pada tahap sosialisasi dan tahap persiapan sedangkan pada tahap pelaksanaan masyarakat sudah tidak dilibatkan. Masyarakat Kapoposang menganggap selama ini mereka tidak aktif dalam kegiatan-kegiatan pengembangan wisata bahari seperti membuka fasilitasfasilitas bagi wisatawan.

Selanjutnya pemerintah daerah Kabupaten Pangkep mengeluaran Surat Edaran Perjanjian antara Pemerintah Kabupaten Pangkep dengan PT. Makassar Tirta Wisata tentang pengelolaan wisata bahari di Pulau Kapoposang. Didalam surat edaran yang ditanda tangani oleh Bupati Kabupaten Pangkep dengan tegas melarang pihak diluar PT. Makassar Tirta Wisata yang mengaku sebagai pengelola maka kegiatan tersebut dikategorikan sebagai kegiatan ilegal.

Dengan adanya surat edaran ini masyarakat Kapoposang tidak berani untuk mendatangkan wisatawan sendiri karena akan dianggap ilegal. Ini menunjukkan bahwa masyarakat Kapoposang tidak diberi ruang untuk mengelola wilayahnya sendiri dan

Culture \& Society: Journal of Anthropological Research Vol. 3, No. 2, Th. 2021 
berpenghasilan dari potensi yang dimiliki Pulau Kapoposang. Hal ini tentu saja sangat negatif dalam mendukung kegiatan wisata bahari di Kapoposang, seberapa pun usaha yang mereka lakukan seperti membuka fasilitas-fasilitas pelayanan bagi wisatawan ternyata tidak akan memberikan pengaruh positif bagi peningkatan penghasilan tambahan bagi masyarakat.

Berbagai pertemuan baik yang diadakan pemerintah maupun investor, masyarakat diajak terlibat dalam sosialisasi kebijakan serta perencanaan pengembangan wisata bahari namun ini hanya sebatas sosialisasi yang akan dilaksanakan tanpa mendengar aspirasi masyarakat. Dalam pariwisata pun hanya 8 orang yang dijadikan karyawan oleh PT. Makassar Tirta Wisata dan bahkan mereka adalah keluarga yang memiliki lokasi tersebut.

Fasilitas penunjang wisata bahari yang tersedia di Kapoposang lebih banyak dikembangkan oleh pemerintah daerah, swasta, serta BKKPN. Dalam objek wisata bahari ini masyarakat tidak ada yang terlibat dalam penyediaan jasa maupun penyediaan alat-alat. Seperti yang dikemukakan oleh salah satu dari masyarakat.

"Masyarakat disini tidak dilibatkan dalam pariwisata jadi mereka tidak bisa menyediakan jasa maupun menyewakan alat-alat selam. Ini juga karena harrus punya modal besar untuk menyiapkan itu semua".

Kondisi ini menunjukkan masyarakat Pulau Kapoposang belum banyak yang terlibat dalam mengembangkan fasilitas penunjang wisata bahari di pulaunya sendiri. Dalam posisi masyarakat seperti ini sudah dapat diperkirakan kuat dampak positif dari perkembangan wisata bahari akan banyak dinikmati hanya oleh orang atau kelompok non masyarakat setempat seperti pihak dari travel PT. Makassar Tirta Wisata dan pemerintah. Kegiatan-kegiatan wisata bahari yang tidak terlalu melibatkan masyarakat akan mengakibatkan munculnya persepsi dan pandangan masyarakat bahwa kawasan bahari mereka hanya digunakan dan dimanfaatkan oleh kelompok masyarakat luar. Kondisi seperti ini sudah mulai nampak dari masyarakat.

"Masyarakat disini sama sekali tidak dilibatkan dalam pariwisata Pak Andi disana, ituji baru juga mulai tahun kemarin ada sumbangan listrik untuk masyarakat selama bulan puasa tapi itu tidak seberapaji untuk kita karena hanya 3.000.000 saja dikasih untuk bayar listrik masyarakat sedangkan kalau mau dipikir penghasilannya saja sebulan bisa sampai puluhan juta, hampir tiap minggu wisatawan datang kesini"

"Masyarakat disini tidak ada dilibatkan dalam pariwisatanya Pak Andi, masyarakat disini hanya mencari nafkah murni dari memancing ikan kerapuh dan Sunu, tidak ada lagi yang lain. Jadi, kalau mereka tidak melaut mereka hanya diam saja di rumah tidak ada lagi penghasilan padahal kalau dipikir banyak yang bisa dihasilkan dari pariwisata".

Cara pandang masyarakat setempat ini terhadap program dan kegiatan wisata bahari di pulaunya merupakan salah satu determinan yang menentukan perkembangan wisata bahari di pulau ini. Ini menunjukkan bahwa partisipasi masyarakat masih rendah dan belum banyaknya ide-ide yang mengarah pada pengembangan kelembagaan.

Selanjutnya pada usaha kerajinan tangan atau cenderamata. Pulau Kapoposang mempunyai banyak potensi untuk dijadikan kerajinan tangan tetapi masyarakat tidak dilibatkan dalam wisata bahari bahkan pihak PT. Makassar Tirta Wisata pun tidak mengetahui adanya masyarakat yang mempunyai keahlian khusus dalam membuat kerajinan tangan.

Seseorang karyawan dari BKKPN Kupang (Balai Kawasan Konservasi Perairan Nasional) mengemukakan pendapatnya tentang cenderamata (souvenir).

Culture \& Society: Journal of Anthropological Research Vol. 3, No. 2, Th. 2021 
"BBKPN Kupang sudah mengadakan alat sablon bagi masyarakat, itu atas permintaan masyarakat sendiri agar mereka mampu membuat kenangkenangan/oleh-oleh dari Kapoposang. Dana ini didapat dari COREMAP tapi saat ini alat tersebut belum dipakai karena kendala masyarakat yang mau membuat koperasi tapi sampai saat ini alur koperasinya belum jelas"

Bisa dilihat souvenir yang berada di tempat wisata bahari maju di daerah lainnya sudah menjadi penunjang bagi kehidupan ekonomi masyarakat tetapi kenyataannya di Pulau Kapoposang belum berlangsung sebagaimana diharapkan. Banyak penyebabnya, diantaranya masyarakat yang tidak dilibatkan dalam wisata bahari yang dimiliki oleh pihak pengusaha dan akhirnya mereka harus berusaha sendiri untuk memasarkan kerajinan tangannya, peralatan yang kurang memadai untuk membuat ukiran kayu, serta alat sablon yang sampai saat ini belum bisa difungsikan oleh masyarakat. Pengembangan wisata bahari tidak akan baik apabila sumber daya manusia yang menunjang wisata bahari masih kurang, ini juga nantinya akan menjadi dampak pada pembangunan wisata bahari karena akan menurunnya jumlah wisatawan yang berkunjung ke Pulau Kapoposang.

Pada pihak PT. Makassar Tirta Wisata sebagai pengelola objek wisata di Kapoposang seharusnya memberi pemahaman masyarakat terhadap pasar wisatawan, sehingga suatu produk kerajinan tangan dapat selain mendatangkan keuntungan ekonomi bagi masyarakat juga memberikan esensi dari wisata itu sendiri, yaitu berupa kenangan atau pengalaman yang tak terlupakan bagi wisatawan.

Keterlibatan masyarakat sangat ditentukan oleh sejauh mana masyarakat mampu berpartisipasi dan berperan serta dalam setiap kegiatan wisata bahari di Pulau Kapoposang. Kendala pendidikan, keterampilan, pandangan, wawasan, kemampuan berbahasa asing, keberanian dalam berkomunikasi dan interaksi sosial dengan wisatawan, kemampuan membangun jaringan atau hubungan kerja dengan pihak-pihak yang terlibat dalam program wisata bahari, dan ketetapan strategi, kebijakan dan program pembangunan wisata bahari yang dikembangkan pemerintah daerah dan swasta akan sangat menentukan tinggi dan rendahnya keterlibatan masyarakat dalam kegiatan wisata bahari di Pulau Kapoposang.

Hobley (1996) merumuskan level/tingkat bentuk partisipasi yaitu, a. Partisipasi Manipulasi (Manipulatif Participation), karakteristik dari model ini adalah keanggotaan yang bersifat keterwakilan pada suatu komisi kerja, organisasi kerja atau kelompok-kelompok dan bukannya pada individu. b. Partisipasi pasif (Passive Participation) partisipasi rakyat dilihat dari apa yang telah diputuskan atau apa yang telah terjadi, informasi datang dari administrator tanpa mau mendengar respon dari masyarakat tentang keputusan atau informasi tersebut. c. Partisipasi melalui konsultasi (Participation by Consultation), partisipasi rakyat dengan berkonsultasi atau menjawab pertanyaan. Orang dari luar mendefinisikan masalah-masalah dan proses pengumpulan informasi, dan mengawasi analisis. Proses konsultasi tersebut tidak ada pembagian dalam pengambilan keputusan, dan pandangan-pandangan rakyat tidak dipertimabangkan oleh orang luar. d. Partisipasi untuk intensif (Participation for Material Insentive), partisipasi rakyat melalui dukungan berupa sumber daya, misalnya tenaga kerja, dukungan pangan, pendapatan atau insentif material lainnya. Petani menyediakan lahan dan tenaga kerja, tetapi mereka tidak dilibatkan dalam proses percobaan-percobaan dan pembelajaran. Kelemahan dari model ini adalah apabila insentif habis, maka tekonologi yang digunakan dalam program juga tidak akan berlanjut. e. Partisipasi fungsional (Functional Participation), partisipasi rakyat dilihat oleh lembaga eksternal sebagai tujuan akhir untuk mencapai target proyek, khususnya mengurangi biaya. Rakyat mungkin berpartisipasi melalui pembentukan kelompok untuk penentuan tujuan yang terkait dengan proyek. Keterlibatan seperti ini mungkin cukup menarik, karena mereka dilibatkan dalam pengambilan keputusan. Tetapi hal ini terjadi setelah keputusan utamanya telah ditetapkan oleh orang dari luar desa tersebut. Pendeknya, masyarakat desa

Culture \& Society: Journal of Anthropological Research Vol. 3, No. 2, Th. 2021 
"dikooptasi" untuk melindungi target dari orang luar desa tersebut. f. Partisipasi interaktif (Interactive Participation), partisipasi rakyat dalam analisis bersama mengenai pengembangan perencanaan aksi dan pembentukan atau penekanan lembaga lokal. Partisipasi lokal dilihat sebagai hak dan tidak hanya merupakan suatu cara untuk mencapai suatu target proyek saja. Proses melibatkan multi disiplin metodologi, ada proses belajar yang terstruktur. Pengambilan keputusan bersifat lokal oleh kelompok dan kelompok menentukan bagaimana ketersediaan sumber daya digunakan, sehingga kelompok tersebut memiliki kekuasaan untuk menjaga potensi yang ada. g. Partisipasi Inisiatif (Self-Mobilisation), partisipasi masyarakat melalui pengambilan inisiatif secara independen dari lembaga luar untuk perubahan sistem. Masyarakat mengembangkan hubungan dengan lembaga eksternal untuk advice mengenai sumber daya dan teknik yang mereka perlukan, tetapi juga tetap mengawasi bagaimana sumber daya tersebut digunakan.

Dilihat dari level/tingkatan bentuk partisipasi masyarakat ini dapat disimpulkan bahwa partisipasi masyarakat masih rendah, hal ini dikategorikan pada level/tingkatan bentuk pastisipasi pasif yang di mana ada partisipasi masyarakat dilihat melalui penyampaian apa yang telah terjadi atau yang telah dilakukan oleh pihak pemerintah/pelaku pembangunan. Informasi yang ada hanya menjadi milik profesional dari luar dan tanpa mau mendengar respon dari masyarakat tentang keputusan dan informasi tersebut.

Dalam pengembangan wisata bahari masyarakat ada yang merasa diuntungkan oleh pihak swasta tetapi ada pula yang merasa dirugikan dari pengembangan wisata bahari tersebut. Dusun Kapoposang mengemukakan tentang keuntungan yang dirasa masyarakat dalam wisata bahari.

"Kalau dari saya sendiri banyak diuntungkan karena dari sini banyak masuk sumbangan bagi masyarakat"

Sedangkan ada masyarakat yang bekerja sebagai nelayan mengemukakan pendapatnya tentang kerugian yang dirasakan dalam pengembangan wisata bahari di Pulau Kapoposang.

"Saya sebagai nelayan merasa rugi karena banyak pembom dan pembius garagara sosialisasi pariwisata. Sebenarnya ini juga sama dengan merugikan pariwisata, menghancurkan karang dan mengurangi pendapatan nelayan. Dibandingkan dengan dulu-dulu pendapatan nelayan sekaramg sangat jauh berbeda, orang dulu lebih sejahtera dibanding sekarang".

Ini disimpulkan bahwa dari pihak masyarakat merasa bahwa promosi wisata bahari yang dilakukan di Pulau Kapoposang ini merugikan masyarakat terutama bagi nelayan karena banyak nelayan dari luar pulau lain datang ke sekitar Pulau Kapoposang untuk mem-bom dan membius karena mereka menganggap terumbu karang di Kapoposang bagus yang berarti akan banyak mendapatkan ikan. Sedangkan dari pihak pemerintah Kapoposang menganggap dengan adanya wisata bahari ini banyak sumbangan masuk untuk Pulau Kapoposang. Dalam hal ini sebenarnya akan menjadi dampak negatif pada pulaunya sendiri karena potensi utama Pulau Kapoposang terdapat pada potensi bawah air yang sangat indah yang seharusnya pihak yang terkait dan pihak utama masyarakat dalam wisata bahari ini saling bersinergi bertugas untuk menjaga sekitar Pulau.

Adapun bentuk partisipasi masyarakat setempat seperti menjaga kebersihan pulau dengan mengadakan kerja bakti, partisipasi pengadaan lapangan olahraga dan menjaga keamanan pulau. Masyarakat mengemukakan pendapatnya tentang partisipasi yang dilakukan masyarakat setempat.

Culture \& Society: Journal of Anthropological Research Vol. 3, No. 2, Th. 2021 


\begin{abstract}
"Kerja Bakti di Pulau ini jarang tetapi banyak masyarakat yang mau mengusulkan agar kerja bakti terlaksana seminggu sekali, tidak jauh-jauhlah mereka hanya membersihkan pekarangan rumah dan pesisir pantai yang ada di belakang rumah masing-masing dengan begitu juga Kapoposang akan terlihat lebih indah"
\end{abstract}

"Kalau masyarakat di RT 3 sama 4 ini kami buat lapangan futsal sederhana, ada lapangan kosong dekat mercusuar tapi karena lapangannya kecil jadi kita pakai untuk futsal saja dan gawangnya dibuatkan dari bambu saja. Masyarakat disini senang main bola, kalau pemancing semua tidak pergi melaut pasti sorenya kita main bola"

"Mayarakat disini sangat menjaga pulaunya, setiap malam juga ada yang keliling untuk melihat-melihat situasi, kadang juga kalau ada masalah di kampung cepat diselesaikan untungnya masyarakat disini kalau ada masalah tidak sampai berlarutlarut"

Dilihat dari level/tingkat partisipasi masyarakat bukan hanya partisipasi pasif tetapi juga ada pada level/tingkat Partisipasi interaktif (Interactive Participation) yang di mana masyarakat Kapoposang masih ikut serta dalam pengelolaan pulaunya sendiri dengan pengambilan keputusan bersifat lokal oleh kelompok dan kelompok juga yang menentukan bagaimana ketersediaan sumber daya yang digunakan, sehingga kelompok tersebut memiliki kekuasaan untuk menjaga potensi yang ada di lingkungannya. Kerja bakti masih sering dilakukan untuk kebersihan pulaunya. Partisipasi dilihat juga dalam pengadaan lapangan olahraga yang di mana membuat masyarakat masih memikirkan aktivitas disaat mereka tidak pergi laut serta partisipasi dalam keamanan pulau, masyarakat yang punya kepedulian menjaga potensi yang ada di lingkungannya dengan bergantian berkeliling pulau melakukan patroli dan melihat jikalau ada nelayan pem-bom dan pembius yang datang ke pulaunya.

\title{
Kesimpulan
}

Dari data-data yang diperoleh menunjukkan bahwa masyarakat aktif secara optimal hanya pada tahap sosialisasi dan tahap persiapan sedangkan pada tahap pelaksanaan masyarakat sudah tidak dilibatkan. Selama ini masyarakat Pulau Kapoposang tidak aktif dalam kegiatankegiatan pengembangan wisata bahari seperti membuka fasilitas-fasilitas bagi wisatawan. Berdasarkan hasil penelitian ini dapat ditarik kesimpulan ada 2 level/tingkat bentuk partipasi masyarakat yang ada di Pulau Kapoposang yaitu Partisipasi Pasif dan Partisipasi Interaktif yang di mana partisipasi pasif menunjukkan ada partisipasi masyarakat yang dilihat melalui penyampaian ketika apa yang telah terjadi atau yang telah dilakukan oleh pihak pemerintah/pelaku pembangunan. Informasi yang ada hanya menjadi milik profesional dari luar dan tanpa mau mendengar respon dari masyarakat tentang keputusan dan informasi tersebut sedangkan partisipasi interaktif yang di mana masyarakat Kapoposang masih ikut serta dalam pengelolaan pulaunya sendiri dengan pengambilan keputusan bersifat lokal oleh kelompok dan kelompok juga yang menentukan bagaimana ketersediaan sumber daya yang digunakan, sehingga kelompok tersebut memiliki kekuasaan untuk menjaga potensi yang ada di lingkungannya.

Culture \& Society: Journal of Anthropological Research Vol. 3, No. 2, Th. 2021 
Andi Oktami Dewi Artha Ayu Purnama Partisipasi Masyarakat dalam Pengembangan Wisata Bahari Pulau Kapoposang Kabupaten Pangkep Sulawesi Selatan

\section{Daftar Pustaka}

Adi,. (2007). Intervensi Komunitas Pengembangan Masyarakat Sebagai Upaya Pemberdayaan Masyarakat. Jakarta : PT Rajagrafindo Persada.

Apriyani, R. (2012). Partisipasi Masyarakat Dalam pelestarian Hutan Mangrove Di Desa Eretan Kulon Kecamatan Kandanghaur Kabupaten Indramayu. Universitas Pendidikan Indonesia.

Ariana, N. (2012). Pembangunan Pariwisata Bali yang Berkelanjutan Dalam Perspektif Postmodernisme. Fakultas Pariwisata UNUD.

Binarwan, R. (2008). Pengembangan Objek Wisata di Kawasan Pantai Selatan Sukabumi. Jurnal Kepariwisataan Indonesia, 3(1).

Cohen JM, Uphoff NT. (1979). Rural Development Participation. New York [US]: Cornel University

Ghofar, et al. (2017). Partisipasi Masyarakat dalam Pengembangan Wisata Bahari di Pantai Sandranan Kabupaten Gunungkidul Yogyakarta. Journal of Maquares, 6(4).

Hobley, M. (1996). Participatory forestry: The process of change in India and Nepal. In Rural Development Forestry Study Guide 3. London: Rural Development Forestry Network.

Khairuddin, K. (1992). Pembangunan Masyarakat Tinjauan Aspek: Sosiologi, Ekonomi, dan Perencanaan. Yogyakarta: Liberty.

Nawawi, A. (2011). Partisipasi Masyarakat Dalam Pengelolaan Wisata Pantai Depok Parangtritis Kretek Bantul Yogyakarta. Sekolah pasca Sarjana Universitas Gadjah Mada, Yogyakarta.

Ndraha, T. (1987). Pembangunan Masyarakat: Mempersiapkan Masyarakat Tinggal Landas. Jakarta: Bina Aksara.

Paturusi, Samsul A. (2001). Perencanaan Tata Ruang Kawasan Pariwisata, Materi Kuliah Perencanaan Kawasan Pariwisata. Program Pasca Sarjana Universitas Udayana Denpasar, Bali.

Saktiawan, F. (2008). Partisipasi Masyarakat Dalam Pengembangan Desa Wisata (Kasus Di Desa Wisata Sambi, Kecamatan Pakem, Kabupaten Sleman). Program Pasca Sarjana, Universitas Hasanuddin, Makassar.

Sallatu, M. (2007). Partisipasi Stakeholder dalam Formulasi RPJP-D Kabupaten Jeneponto Tahun 2006-2026. Program Pascasarjana. Universitas Hasanuddin. Makassar.

Sari, D. (2011). Pengembangan Pariwisata Obyek Wisata Pantai Sigandu Kabupaten Batang. Fakultas Ekonomi Universitas Diponegoro, Semarang.

Setiyarti, T et al. (2020). Partisipasi Masyarakat dalam Pengembangan Objek Wisata Pantai Berawa Tibubeneng. Jurnal Capital, 3(2).

Susanti, Y. (2012). Partisipasi Masyarakat Lokal Dalam Pengembangan Objek Wisata Goa Tabuhan Seabagai Daerah Tujuan Wisata (Tourist Destination Area) Di Desa Wareng Kecamatan Punung Kabupaten Pacitan. Fakultas Keguruan Dan Ilmu Pendidikan Universitas Sebelas Maret, Surakarta.

Tuwo, A. (2011). Pengelolaan Ekowisata Pesisir Dan Laut Pendekatan Ekologi, Sosial-Ekonomi, Kelembagaan, dan Sarana Wilayah. Brilian Internasional. Surabaya.

Wisyasmi, K. (2012). Strategi Pengelolaan Pariwisata Bahari Di Kecamatan Bayah Kabupaten Lebak. Fakultas Ilmu Sosial Dan Ilmu Politik Universitas Sultan Ageng Tirtayasa, Serang. 